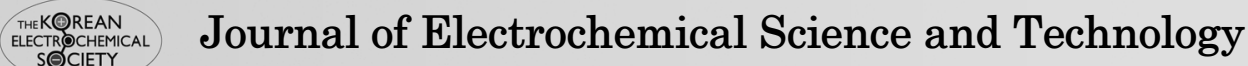

jecst.kecs.or.kr

\title{
The Operation of Polymer Electrolyte Membrane Fuel Cell using Hydrogen Produced from the Combined Methanol Reforming Process
}

\author{
Sang Sun Park ${ }^{1}$, Yukwon Jeon², Jong-Man Park², Hyeseon Kim ${ }^{1}$, Sung Won Choi², \\ Hasuck Kim ${ }^{3}$, and Yong-Gun Shul',* \\ ${ }^{1}$ lotte chemical, \#24-1 Jang-dong, Yuseong-Gu, Daejeon-city. 305-726, Republic of Korea \\ ${ }^{2}$ Department of Chemical and Biomolecular Engineering, Yonsei University, 50 Yonsei-ro, Seodaemun-gu, Seoul 120-749, \\ Republic of Korea \\ ${ }^{3}$ Department of Energy Systems Engineering, Daegu Gyeongbuk Institute of Science \& Technology (DGIST), 50-1 Sang-Ri, \\ Hyeonpung-Myeon, Dalseong-Gun, Daegu 711-873, South Korea
}

\begin{abstract}
A combined system with PEMFC and reformer is introduced and optimized for the real use of this kind of system in the future. The hydrogen source to operate the PEMFC system is methanol, which needs two parts of methanol reforming reaction and preferential oxidation (PROX) for the hydrogen fuel process in the combined operation PEMFC system. With the optimized methanol steam reforming condition, we tested PROX reactions in various operation temperature from 170 to $270{ }^{\circ} \mathrm{C}$ to investigate $\mathrm{CO}$ concentration data in the reformed gases. Using these different $\mathrm{CO}$ concentration, PEMFC performances are achieved at the combined system. $\mathrm{Pt} / \mathrm{C}$ and $\mathrm{Ru}$ promoted $\mathrm{Pt} / \mathrm{C}$ were catalysts were used for the anode to compare the stability in $\mathrm{CO}$ contained gases. The alloy catalyst of $\mathrm{PtRu} / \mathrm{C}$ shows higher performance and better resistance to $\mathrm{CO}$ than the $\mathrm{Pt} / \mathrm{C}$ at even high $\mathrm{CO}$ amount of $200 \mathrm{ppm}$, indicating a promotion not only to the activity but also to the $\mathrm{CO}$ tolerance. Furthermore, in a system point of view, there is a fluctuation in the PEMFC operation due to the unstable fuel supply. Therefore, we also modified the methanol reforming by a scaled up reactor and pressurization to produce steady operation of PEMFC. The optimized system with the methanol reformer and PEMFC shows a stable performance for a long time, which is providing a valuable data for the PEMFC commercialization.
\end{abstract}

Keywords : Methanol reforming, Preferential oxidation(PROX), PolymerElectrolyte MembraneFuel Cell(PEMFC), Alloy catalyst Received : 9 April 2016, Revised : 3 May 2016, Accepted : 4 May 2016

\section{Introduction}

Fuel Cell Vehicles are achieving energy efficiencies of 40 to 50 percent in current road tests compared to 10 to 16 percent in conventional vehicles. Fuel cell vehicle can have twice as efficient at least than advanced vehicle like gasoline/battery hybrids [1]. Most of studies for on-board hydrogen production for fuel cells are based on two types of carbon compounds. One is oxygen-containing compounds,

*E-mail address: shulyg@yonsei.ac.kr

DOI: http://dx.doi.org/10.5229/JECST.2016.7.2.146 methanol, ethanol and etc. The others are hydrocarbons such as ethers (dimethylether, etc), natural gas, propane gas, gasoline, jet fuel and diesel fuel. Automotive Polymer Electrolyte Membrane Fuel Cell (PEMFC) requires hydrogen gas to operate. The most convenient way to obtain the gas would be to use an on-board fuel processor to convert or reform commonly available liquid fuels, such as gasoline, methanol, and ethanol, into hydrogen.

One of the major challenges to PEMECs system for vehicle has been the low tolerance to carbon monoxide on the fuel cell anode. For conventional fuel cells, the carbon monoxide levels need to be below 
$10 \mathrm{ppm}$, which in turn requires the use of additional reactors, such as water-gas shift(WGS) and preferential oxidation(PROX), or membrane purifier $[2,3]$. Compared to processor using higher hydrocarbon fuels, methanol processor has an advantage [7]. Their product stream often contains $1 \%$ or less $\mathrm{CO}$ on a dry gas basis. In that case, the WGS reactors can be eliminated. However, further clean-up using either a membrane or PROX reactor is still required, these additional reactors increase the size and complexity of the reformer system while often lowering the efficiency [8-10].

The PROX catalyst should ideally exhibit both activity and selectivity toward $\mathrm{CO}$ oxidation in the presence of $\mathrm{H}_{2}$. Reported catalysts used for the selective oxidation of $\mathrm{CO}$ in presence of $\mathrm{H}_{2}$ are predominantly based upon either supported noble metals or mixed metal oxides [12]. The use of noble metals such as platinum, palladium and ruthenium is favorable from the viewpoint of their high activity and selectivity for $\mathrm{CO}$ oxidation in the temperature range up to $200{ }^{\circ} \mathrm{C}[9]$. The high activity and selectivity of the catalysts arises from the strong preferential binding of $\mathrm{CO}$ over $\mathrm{H}_{2}$. Additionally, any reduction in the precious metal requirement via either promotion or substitution with suitable transition metals would be beneficial regarding cost [9]. $\mathrm{CuO}-\mathrm{CeO}_{2}$ catalysts have been shown to be very active for $\mathrm{CO}$ oxidation in hydrogen rich gas without using precious metals. The mixedoxide catalysts were better than other catalysts like the conventional copper-based and platinum, palladium and ruthenium in terms of activity and selectivity [8].

The fuel processing system consists of a steam reforming catalyst layer which converts methanol and water to a hydrogen-rich gas as illustrated in equation (1) and $\mathrm{CuO}-\mathrm{CeO}_{2}$ catalyst layer for preferential CO oxidation to remove the $0.5 \sim 0.8 \%$ of carbon monoxide present in the reforming gas to below $10 \mathrm{ppm}$ shown in equation (4) [4-6].

Methanol steam reforming

$$
\begin{aligned}
& \mathrm{CH}_{3} \mathrm{OH}+\mathrm{H}_{2} \mathrm{O} \leftrightarrow \mathrm{CO}_{2}+3 \mathrm{H}_{2}, \\
& \Delta \mathrm{H}_{\mathrm{f}}^{\mathrm{o}}=49.4 \mathrm{kJmol}^{-1} \\
& \mathrm{CH}_{3} \mathrm{OH} \leftrightarrow \mathrm{CO}+2 \mathrm{H}_{2}, \\
& \Delta \mathrm{H}_{\mathrm{f}}^{\mathrm{o}}=90.5 \mathrm{kJmol}^{-1} \\
& \mathrm{CO}+\mathrm{H}_{2} \mathrm{O} \leftrightarrow \mathrm{CO}_{2}+\mathrm{H}_{2} \\
& \Delta \mathrm{H}_{\mathrm{f}}^{\mathrm{o}}=-41.1 \mathrm{kJmol}^{-1}
\end{aligned}
$$

Preferential oxidation

$$
\begin{aligned}
& \mathrm{CO}+\mathrm{H}_{2}+\mathrm{O}_{2} \leftrightarrow \mathrm{CO}_{2}+\mathrm{H}_{2} \mathrm{O} \text { (desired), } \\
& \Delta \mathrm{H}_{\mathrm{f}}^{\mathrm{o}}=-524.3 \mathrm{kJmol}^{-1} \\
& \mathrm{H}_{2}+1 / 2 \mathrm{O}_{2} \rightarrow \mathrm{H}_{2} \mathrm{O} \text { (undesired) }
\end{aligned}
$$

In this study, we demonstrate a PEMFC system with methanol fuel process that is mainly composed by two parts of methanol reforming reaction and preferential oxidation (PROX). The optimized operation conditions such as temperature were investigated for these two parts at the methanol fuel process system. Furthermore, the combined system with PEMFC was evaluated by various operation conditions and catalysts to study the enhancing efficiency and stability of the system, which could be a valuable data for the fuel cell commercialization.

\section{Experimental Section}

\subsection{Reforming system}

Two parts of the reforming system were designed to produce hydrogen and reduce $\mathrm{CO}$, as shown in Fig. 1. First, methanol and water for a steam reforming was fed into the reformer reactor under the commercial catalyst of ICI 33-5 as a $\mathrm{MeOH}$ reforming catalyst. Table 1 shows chemical composition and physical properties of ICI 33-5. For the beginning system, $1 \mathrm{~g}$ of ICI 33-5 catalyst with a particle size of 40-50 mesh was packed into a 1/4 inch stainless steel reactor. Before the $\mathrm{MeOH}$ reforming reaction, the catalyst was reduced under $\mathrm{H}_{2}$ for $2 \mathrm{hr}$. A pump (FMI LAB PUMP, Model QG 150) supplied the mixture of methanol and water (molar ratio 1:2) to the vaporizer with a liquid $\mathrm{MeOH}$ flow rate of $0.1 \mathrm{~mL} / \mathrm{min}$ [7]. In the modified system, $4 \mathrm{~g}$ of ICI 33-5 catalyst of same size was packed into a bigger $1 / 2$ inch stainless reactor. The catalyst was also reduced under $\mathrm{H}_{2}$ for $2 \mathrm{~h}$. A pump (Syringe Pump, Model KDS200) supplied the mixture of methanol and water (molar ratio 1:2) to the vaporizer with a liquid $\mathrm{MeOH}$ flow rate of 0.08 $\mathrm{ml} / \mathrm{min}$. The vapor was reacted inside of reformer and the reactor generated a hydrogen rich stream.

For the preferential oxidation, $20 \% \mathrm{CuO}-\mathrm{CeO}_{2}$ catalysts were prepared by co-precipitation, the precursor salts of $\mathrm{Cu}\left(\mathrm{NO}_{3}\right)_{2} \bullet 3 \mathrm{H}_{2} \mathrm{O}$ and $\mathrm{Ce}\left(\mathrm{NO}_{3}\right)_{3} \bullet 6 \mathrm{H}_{2} \mathrm{O}$, were dissolved in deionized water, mixed together and heated to $70{ }^{\circ} \mathrm{C}$. $\mathrm{NaOH}$ solution was added drop- 


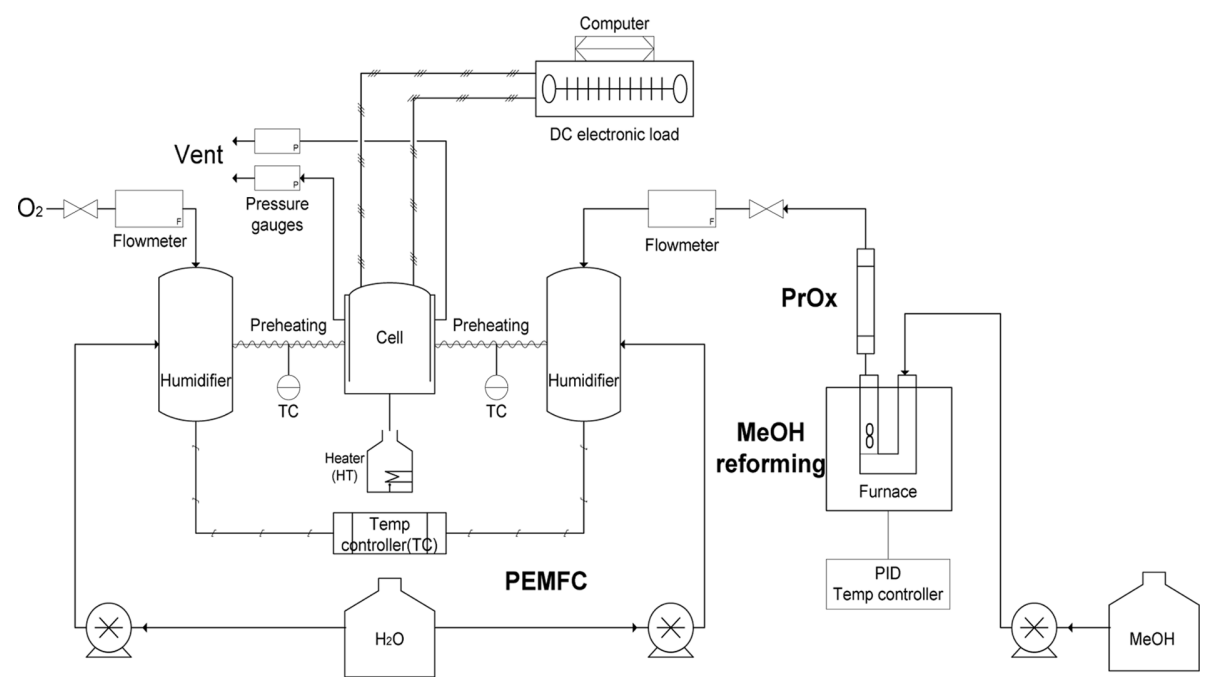

Fig. 1. The schematic diagram of PEMFC with fuel process.

Table 1. Properties of ICI 33-5 reforming catalyst

\begin{tabular}{cc}
\hline \hline $\mathrm{Cu}(\mathrm{wt} \%)$ & 60.6 \\
$\mathrm{Al}_{2} \mathrm{O}_{3}(\mathrm{wt} \%)$ & 33.8 \\
$\mathrm{ZnO}(\mathrm{wt} \%)$ & 5.6 \\
Catalyst density $\rho\left(\mathrm{g} / \mathrm{cm}^{3}\right)$ & 2.77 \\
BET area $\left(\mathrm{m}^{2} / \mathrm{g}\right)$ & 56 \\
Paricle size $(\mathrm{mm})$ & 3.38 \\
Pore volume $(\mathrm{mL} / \mathrm{g})$ & 0.23 \\
\hline
\end{tabular}

wise to precipitate the metals as hydroxides under vigor us stirring and the precipitate was aged with stirring at $70{ }^{\circ} \mathrm{C}$ for $5 \mathrm{~h}$. The $\mathrm{pH}$ of the mixed solution was kept at 10 . The precipitate was filtered and washed with deionized water to remove the residual sodium, and then dried for $12 \mathrm{~h}$ at $90^{\circ} \mathrm{C}$. The dried precipitate was calcined at $500{ }^{\circ} \mathrm{C}$ for $5 \mathrm{~h}$ in air. The calcined catalyst was crushed and sieved to 0.15 $0.18 \mathrm{~mm}$. The BET surface area of the catalyst was $91 \mathrm{~m}^{2} / \mathrm{g}$. The $\mathrm{Cu}$ content in the catalyst was designated as $\mathrm{Cu} /(\mathrm{Cu}+\mathrm{Ce})$ atom ratio100 (at\%) [8]. The reaction experiments were carried out in a $1 / 4 \mathrm{inch}$ stainless steel tube reactor at normal pressure. $3 \mathrm{~g}$ of $20 \% \mathrm{CuO}-\mathrm{CeO}_{2}$ catalyst of 80-100 mesh size was used. A K-type thermocouple was placed at the center of the bed to monitor the reaction temperature.

\subsection{PEMFC system}

The PEMFC system was operated by the reactant from the fuel processor composed of methanol reformer and preferential oxidation reactor, as shown in Fig. 1. The PEMFC performance was tested with a single cell $\left(25 \mathrm{~cm}^{2}\right)$ module. The MEA (Membrane Electrolyte Assembly) was prepared by a procedure of spraying and hot-pressing. Two different catalyst system were tested to find the best option. One is $20 \% \mathrm{Pt} / \mathrm{C}$ (ETek, commercial catalyst) for both the anode and cathode catalysts, and the other is the catalysts of $20 \% \mathrm{PtRu} / \mathrm{C}$ for anode and $20 \% \mathrm{PtCoCr} / \mathrm{C}$ for cathode, which have been prepared by previous methods [9-12]. All of the catalysts were directly sprayed on the Nafion (C) 117 membrane (DuPont) with a loading of $0.2 \mathrm{mg} / \mathrm{cm}^{2} \mathrm{Pt}$. The MEA (Membrane Electrolyte Assembly) was prepared by hot-pressing at $248^{\circ} \mathrm{F}$ for $90 \mathrm{sec}$. The operating temperature and pressure of the fuel cell were $80^{\circ} \mathrm{C}$ and $1 \mathrm{~atm}$, respectively. The reformed gases were fed into the anode and pure $\mathrm{O}_{2}$ was used in the cathode to provide a same reaction condition.

\section{Results and Discussion}

\subsection{Methanol reforming reaction and Preferential oxidation of $\mathrm{CO}$}

For the first part of the reforming system, Fig. 2 shows the $\mathrm{MeOH}$ conversion with respect to the reaction temperature. The mixture of methanol and water was fixed with the molar ratio of 1:2 to compare the effect of the reaction temperature. From different groups, the effect of the water content in the feed on 
the methanol conversion was studied by Kim [7] and Jiang et al. $[13,14]$. When the water to $\mathrm{MeOH}$ ratio was changed from 1 to 2 , there was no great difference in $\mathrm{MeOH}$ conversion as observed by Jiang $[13,14]$. Therefore, it was concluded that the reforming rate is not affected by water partial pressure as long as the partial pressure exceeds the methanol partial pressure. Using this optimized water and methanol molar ratio, the $\mathrm{MeOH}$ conversion drastically increased with increasing temperature from $170{ }^{\circ} \mathrm{C}$ and attained $100 \%$ conversion from above $250{ }^{\circ} \mathrm{C}$. At this condition, it generated $55 \%$ of hydrogen, $18 \%$ of carbon dioxide, $0.2 \%$ of carbon monoxide and $26.8 \%$ of water with a conversion of $100 \%$ at the reaction temperature of $250{ }^{\circ} \mathrm{C}$.

Fig. 3 shows CO conversion with increasing temperature for the second part of preferential oxidation of $\mathrm{CO}$ for the reformer. The air-to-CO ratio was fixed to the value of 1.5 that is known as the most effective

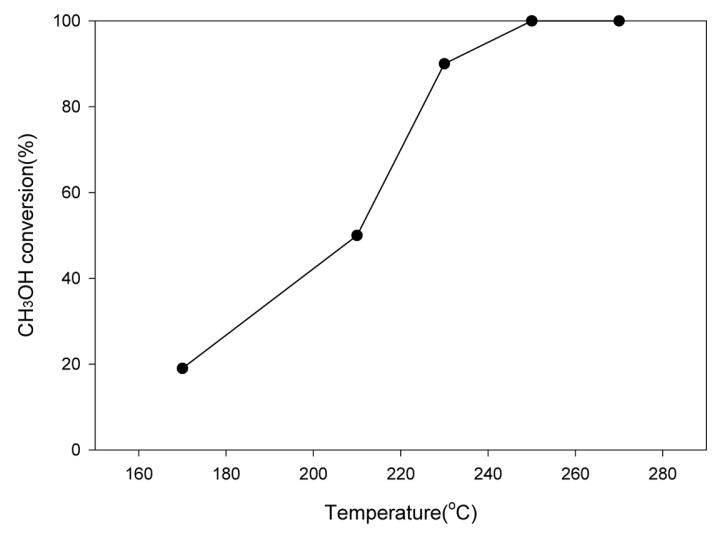

Fig. 2. $\mathrm{MeOH}$ conversion with respect to reforming temperature using ICI 33-5 catalyst.

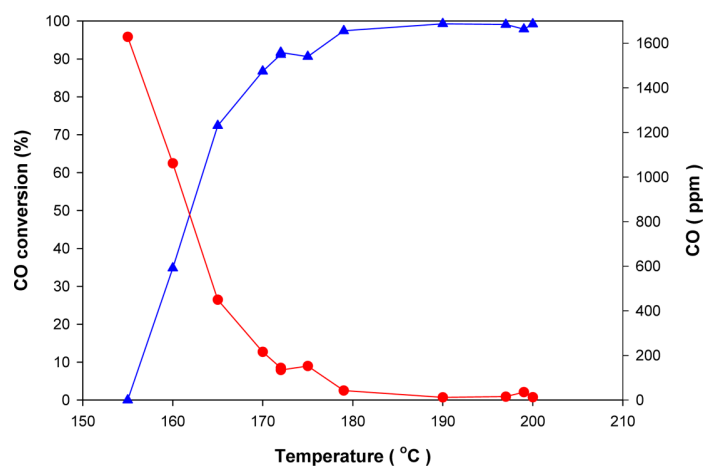

Fig. 3. Conversion of $\mathrm{CO}$ in reformate gas with $\mathrm{PROX}$ reaction temperature using $20 \% \mathrm{CuO}-\mathrm{CeO}_{2}$ catalyst. region [8-9]. By focusing only on the effect of the temperature, it was found that the $\mathrm{CO}$ concentration is decreased especially from the reaction temperature of 170 to 200 with the value range of $200 \mathrm{ppm}$ to 10 $\mathrm{ppm}$. As a result, when the reaction temperatures of the preferential oxidation of CO were 170, 180, 190 and $200{ }^{\circ} \mathrm{C}$, the $\mathrm{CO}$ concentrations were $200 \mathrm{ppm}$, $70 \mathrm{ppm}, 30 \mathrm{ppm}$ and $10 \mathrm{ppm}$, respectively. The $20 \%$ $\mathrm{CuO}-\mathrm{CeO}_{2}$ catalyst reduced the amount of $\mathrm{CO}$ to less than $10 \mathrm{ppm}$ at the very high reaction temperature of 190-200 ${ }^{\circ} \mathrm{C}$. It shows the preferential oxidation of CO needs more amount of $\mathrm{O}_{2}$ than the theoretical stoichiometry. In addition, hydrogen oxidation was also suppressed in parallel with $\mathrm{CO}$ oxidation which required high temperature operation of PROX reaction.

\subsection{PEMFC operation with reformer}

After the optimization of the operation condition of the reformer, the effect of $\mathrm{CO}$ concentration on the PEMFC operation was investigated by the different concentration of $\mathrm{CO}$ in the reformer gas of the fuel processor, which was made by changing the operating con-

(a)

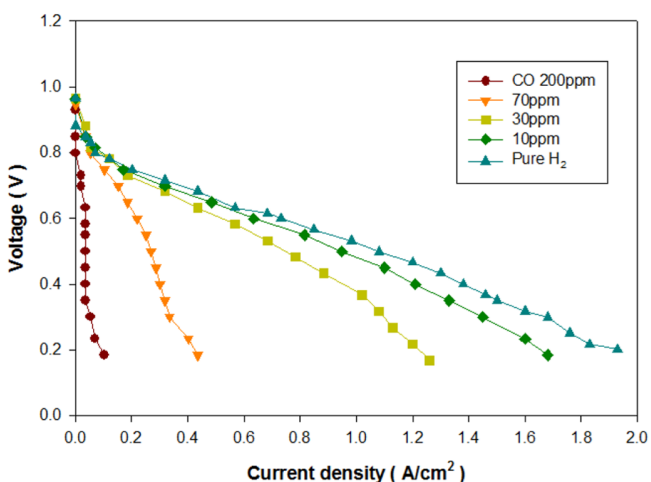

(b)

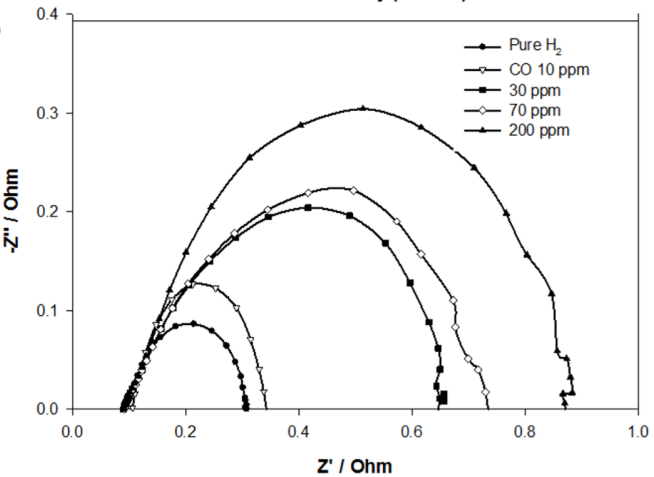

Fig. 4. The (a) performance and (b) impedance study of the $\mathrm{PEMFC}$ with $\mathrm{Pt} / \mathrm{C}$ at anode/cathode as a function of $\mathrm{CO}$ concentration. 
Table 2. Interfacial resistance of MEA about various CO concentration

\begin{tabular}{cccccc}
\hline \hline $\mathrm{CO}(\mathrm{ppm})$ & 0 & 10 & 30 & 70 & 200 \\
\hline Interfacial resistance $(\Omega),(20 \% \mathrm{Pt} / \mathrm{C})$ & 0.196 & 0.235 & 0.543 & 0.629 & 0.762 \\
Interfacial resistance $(\Omega),(20 \% \mathrm{PtRu} / \mathrm{C})$ & 0.142 & 0.143 & 0.181 & 0.489 & 0.599 \\
\hline
\end{tabular}

dition of the PROX reactor. Two different catalysts systems were evaluated by the PEMFC single cell tests.

Fig. 4(a) shows the single cell performance of commercial $\mathrm{Pt} / \mathrm{C}$ catalyst at both electrodes with changing $\mathrm{CO}$ concentration in the reformed gas. As we can expect, the PEMFC performance decreases when the concentration of $\mathrm{CO}$ increases. Almost $90 \%$ of the performance decrease was shown while the $\mathrm{CO}$ concentration was increased to $200 \mathrm{ppm}$ due to the $\mathrm{CO}$ poisoning to the Pt catalyst. The impedance measurement was carried out at $80{ }^{\circ} \mathrm{C}$ by feeding oxygen in the cathode side and the reformer gas into anode side. Fig. 4(b) illustrates the impedance spectra of $\mathrm{Pt} / \mathrm{C}$ with various $\mathrm{CO}$ concentration and $\mathrm{H}_{2}$ gas. Membrane resistance and interfacial resistance were increased by $\mathrm{CO}$ in reformate gas, as listed in Table 2. Interfacial resistance was increased drastically from $30 \mathrm{ppm}$ of CO This is due to preferential adsorption $\mathrm{CO}$ on Pt catalyst compared to hydrogen, which acts as a poison on the catalyst. On the other hand, as shown in Fig. 5(a), although the different catalyst system of $\mathrm{PtRu} / \mathrm{C}$ for anode and $\mathrm{PtCoCr} / \mathrm{C}$ for cathode demonstrations similar PEMFC performance, a better resistance to the $\mathrm{CO}$ was shown for these alloy catalysts from the smaller decrease of the performance with the value around $75 \%$ at the $\mathrm{CO}$ concentration of $200 \mathrm{ppm}$. Impedance spectra of $\mathrm{PtRu} / \mathrm{C}$ with $\mathrm{CO}$ is also shown in Fig. 5(b). MEA interfacial resistance using $\mathrm{PtRu} / \mathrm{C}$ catalyst was slightly reduced at all range of $\mathrm{CO}$ concentration with $\mathrm{CO}$ which is also summarized in Table 2. It is the reason that the PtRu/C catalyst has not only a better activity but also more tolerance on the $\mathrm{CO}$ gas, which provides a promising properties in our system. As we can concluded, the catalytic activity of pure $\mathrm{Pt} / \mathrm{C}$ was higher than that of PtRu/C for pure hydrogen. However, in a view of practiced application, $\mathrm{PtRu} / \mathrm{C}$ as an anode catalyst seems to be more beneficial because of $\mathrm{CO}$ generated in reformatted gases to ensure the stability of integrated operation of PEMFC with fuel processor.

For this combined system, we found a problem of the unstable performance during the reproducibility (a)

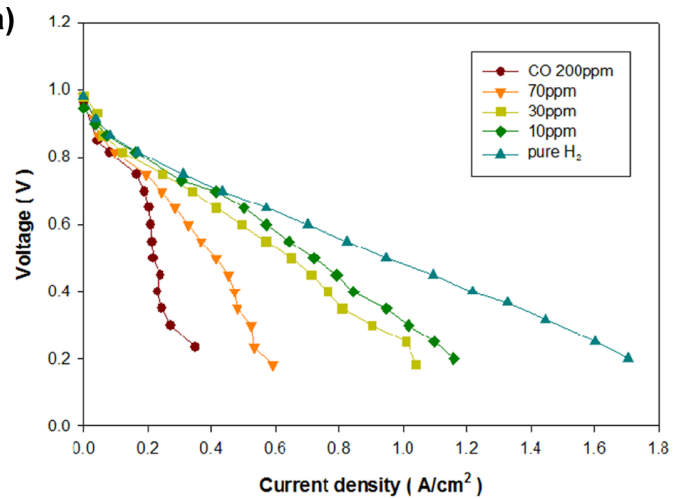

(b)

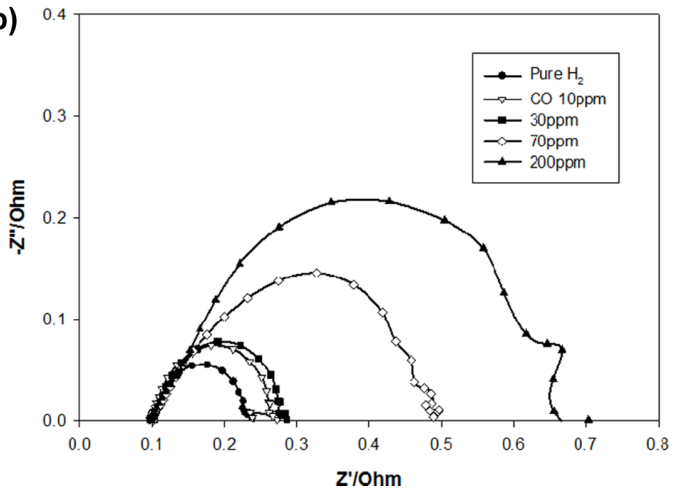

Fig. 5. The (a) performance and (b) impedance study of the $\mathrm{PEMFC}$ with $\mathrm{PtRu} / \mathrm{C}$ (anode) and $\mathrm{PtCoCr} / \mathrm{C}$ (cathode) as a function of $\mathrm{CO}$ concentration.

tests. Fig. 6 (a) shows the PEMFC performance at every 4 min operated by $\mathrm{MeOH}$ reforming system which generates hydrogen containing $10 \mathrm{ppm} \mathrm{CO}$. Unstable performance of the PEMFC was revealed at atmosphere operation for different operation times. Since the PEMFC system has reformer to supply reformed gas, the reactant fuel gases should have no back pressure to overcome that of gases head built into the reformer. With the back pressure in the reforming system, the flow rate in the inlet of PEMFC can be very unstable, since the reactant flows into the reactor by pulses. When the flow rate of fuel gas was unstable, the performance of PEMFC was simultaneously fluctuated as shown in the operation at atmospheric in Fig. 6(b). 
(a)
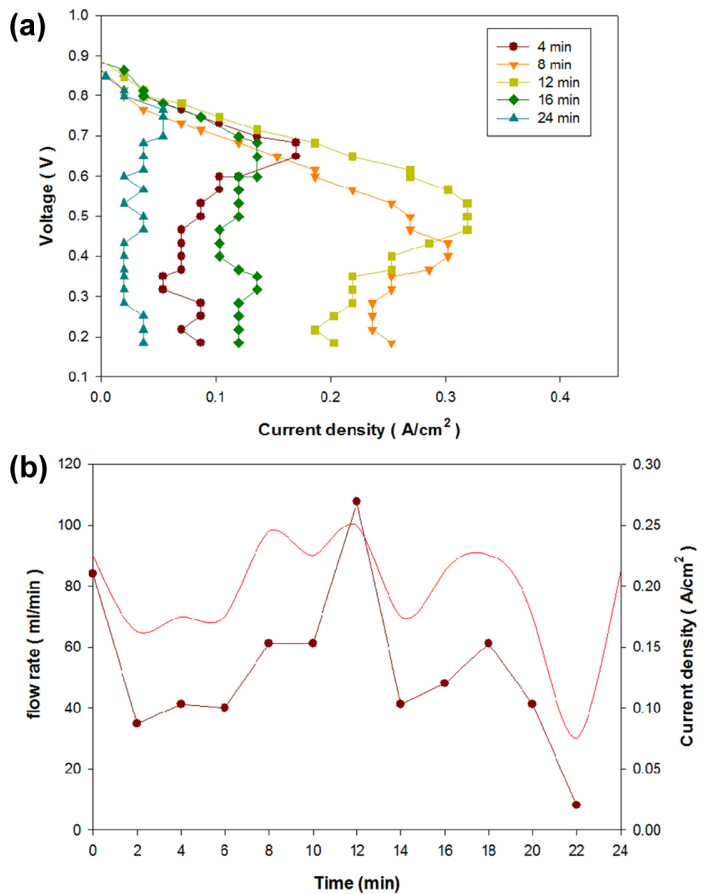

Fig. 6. The flow fluctuation on the fuel cell performance at (a) every $4 \mathrm{~min}$ and (b) during $24 \mathrm{~min}$.

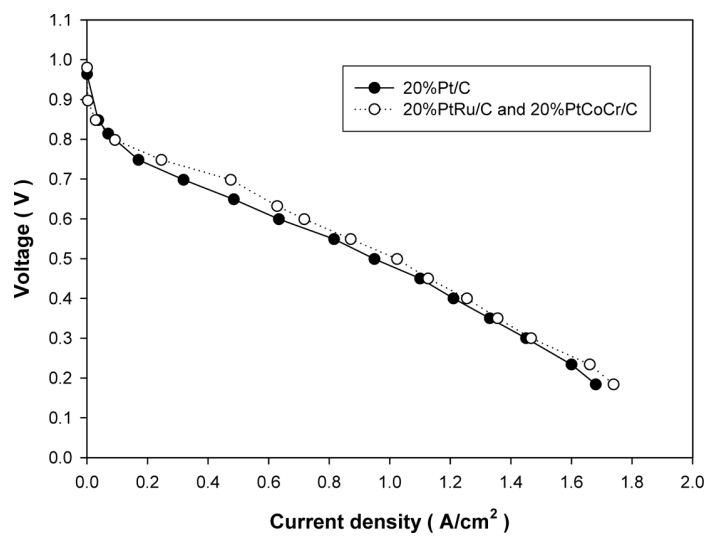

Fig. 7. Performance of $\mathrm{PEMFC}$ with $\mathrm{Pt} / \mathrm{C}$ and $\mathrm{PtRu} / \mathrm{C}$ for each anode catalysts at the modified PEMFC and reformer combined system.

\subsection{System optimization and long-term tests}

In order to overcome the fluctuation, the system modification of the fuel gas PEMFC operation has been attempted. The system was scaled up and the pressure maintained by the high pressure pump with pressure regulator. With this modified system, we can obtain a stable PEMFC performance of $630 \mathrm{~mA} / \mathrm{cm}^{2}$

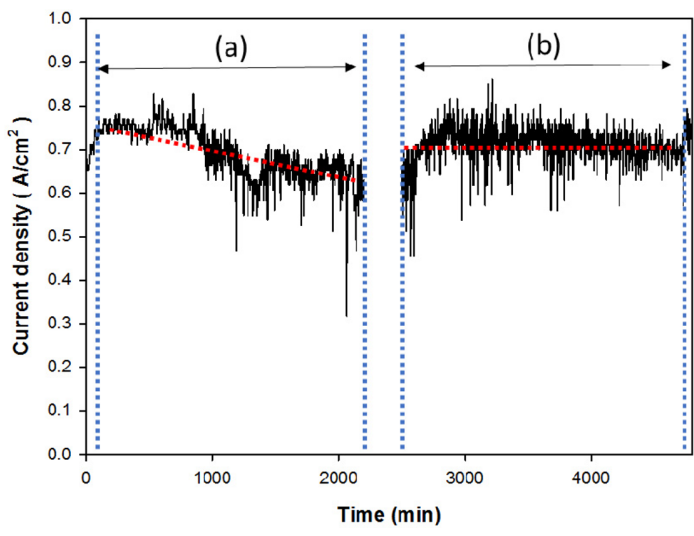

Fig. 8. Long term stability performance of PEMFC with $\mathrm{MeOH}$ reforming process for (a) the original system and (b) modified system.

in $\mathrm{Pt} / \mathrm{C}$, and $717 \mathrm{~mA} / \mathrm{cm}^{2}$ in $\mathrm{PtRu} / \mathrm{C}$ at $0.6 \mathrm{~V}$, which is similar to the previous performance, as shown in Fig. 7 about the performance of catalysts on PEMFC operation with the new fuel processor.

Fig. 8(a) shows PEMFC long term stability tests with the different $\mathrm{MeOH}$ reforming reactors to display the enhancement of the system. For the previous system, we can see the fluctuation with a low performance of fuel cell between 1200 and 2400 minutes, due to the fluctuating flow rate from methanol steam reformer which may be for the recharging of the liquid feed and changing other process parameters. This was avoided by using large a storage tank for methanol fuel for the modified system. After changing the system, the performance lased with a stable long time operation (Fig. 8(b)), indicating the optimization of the PEMFC and fuel processor combined system. This results can provide a valuable data for the commercialization of this kind of system from this advanced study.

\section{Conclusion}

We exhibit a systemically designed combination of PEMFC and methanol fuel process to reveal an enhanced system for the PEMFC commercialization. The fuel processing system is operated to generate hydrogen in situ from a methanol-water mixture for the PEMFC operation. The $\mathrm{MeOH}$ conversion attained $100 \%$ at $250{ }^{\circ} \mathrm{C}$ and it converts to mixture gas consist of hydrogen(rich), water vapor, carbon monoxide, carbon dioxide. The PROX system with 
the $20 \% \mathrm{CuO}-\mathrm{CeO}_{2}$ catalyst completely oxidized the CO concentration to less than $10 \mathrm{ppm}$ at $180-200{ }^{\circ} \mathrm{C}$. By operating the PEMFC, the membrane and interfacial resistance increased as increasing $\mathrm{CO}$ concentration and it drastically decreased the performance. We found that the $\mathrm{PtRu} / \mathrm{C}$ catalyst was beneficial to continue the highly active and stable operation of PEMFC with fuel processor under the certain amount of $\mathrm{CO}$ in the reformed gas. To overcome violently unstable flow rate in the inlet of PEMFC due to the pressure drop in reactor, modified reformer system was also introduced to make a stable PEMFC performance. Finally, we could demonstrate our developed system $(\mathrm{PtRu} / \mathrm{C}$ : anode, $\mathrm{PtCrCo} / \mathrm{C}$ : cathode) for the methanol reformer and PEMFC, which showed high performance and stability.

\section{Acknowledgements}

This research was supported by the Industrial Technology Innovation Program funded by the Ministry Of Trade, Industry and Energy (MOTIE), Republic of Korea (grant number 10052076 and 10052823)

\section{References}

[1] S. Fable and S. Unnasch, Fuel Cell Reformer Emissions, DOE Hydrogen, Fuel Cells and Infrastructure Technologies Annual Review Presentation, (2004).

[2] E. R. Delsman, M. H. J. M. DeCroon, A. Pierik, G. J. Kramer, P. D. Cobden, Ch. Hofmann, V. Cominos and J. C. Schouten, Chem. Eng. Sci., 2004, 59, 4795-4802.

[3] J. D. Holladay, J. S. Wainright, E. O. Jones and S. R. Gano, J. Power Sources, 2004, 130, 111-118.

[4] J. R. Lattner and M. P. Harold, Appl. Catal. B: Environ., 2005, 56, 149-169.

[5] M. Krumpelt, T. R. Krause, J. D. Carter, J. P. Kopasz and S. Ahmed, Catal. Today, 2002, 77, 3-16.

[6] S. K. Kamarudin, , W. R. W. Daud, A. Md. Som, M. S. Takriff, A. W. Mohammad and Y. K. Loke, Chem. Eng. J., 2004, 104, 7-17.

[7] J. K. Lee, J. B. Ko and D. H. Kim, Appl. Catal. A Gen., 2004, 278, 25-35.

[8] D. H. Kim and J. E. Cha, Catal. Letters, 2002, 86, 107112.

[9] C. D. Dudfield, R. Chen and P. L. Adcock, Int. J. Hydrogen Energy, 2001, 26, 763-775.

[10] O. Korotkikh and R. Farrauto, Catal. Today, 2000, 62, 249-254.

[11] J.-D. Kim, Y.-I. Park, K. Kobayashi, M. Nagai and M. Kunimatsu, Solid State Ionics, 2001, 140, 313-325.

[12] V. Recupero, L. Pino, M. Cordaro, A. Vita, F. Cipi편 and M. Laganà, Fuel Processing Tech., 2004, 85, 14451452.

[13] C. J. Jiang, D. L. Trimm, M. S. Wainwright and N. E. Cant, Appl. Catal. A Gen., 1993, 97, 145-158.

[14] C. J. Jiang, D. L. Trimm, M. S. Wainwright, N. W. Appl. Catal. A Gen., 1993, 93, 245-255. 